\title{
ANALISIS PENGARUH THE BIG FIVE PERSONALITY TERHADAP ORGANIZATIONAL CITIZENSHIP BEHAVIOR (OCB) DAN KINERJA PERAWAT DI RS SANTA CLARA MADIUN
}

Vol. 15 - No. 1

April 2015

\author{
Desi Natalia Soepono ${ }^{1}$, Veronika Agustini Srimulyani ${ }^{2}$ \\ ${ }^{1,2}$ Program Studi Manajemen, Fakultas Ekonomi, Universitas Katolik Widya Mandala Madiun \\ 1vedeslofa@yahoo.com, '1vedeslofa@gmail.com, '²veronikaagustinis@yahoo.co.id
}

\begin{abstract}
Nurse performance shows the magnitude of the contribution made by nurses to hospital and reflects the performance of a hospital because patient will often relates and meets the nurse. One factor that affect the nurses performance is organizational citizenship behavior (OCB). $O C B$ is extra-role behavior that nurses are willing to do tasks outside of their job discription and the big five personality is one of the factors that significantly influence the OCB. This study aims to examine the direct and indirect influence of the big five personality to the performance of nurses at Santa Clara Madiun Hospital through OCB as intervening variable.

The sampel of this research were all nurses at Santa Clara Madiun Hospital. Data collection instruments using questionnaires. Data analysis techniques in this study included descriptive statistics, test data quality, classical assumption, hierarchical regression analysis, and path analysis using SPSS 17.0.

The result showed that the big five personality significant positive effect on nurses performance, the big five personality significant positive effect on $O C B$, and $O C B$ significant positive effect on the nurses performance. OCB has a full mediation effect to influence of the big five personality to the nurses performance.
\end{abstract}

Keywords: the big five personality, OCB, performance.

\section{PENDAHULUAN}

Sumber daya manusia adalah faktor terpenting yang membantu perusahaan mencapai tujuannya karena sumber daya manusia yang menggerakkan roda perusahaan. Era globalisasi menuntut sumber daya manusia yang tidak hanya memiliki kemampuan dan keahlian saja, namun juga harus dinamis dan mampu mencerminkan gambaran dari perusahaan tempat ia bekerja melalui kinerjanya. Demikian pula dalam sebuah perusahaan yang bergerak di bidang jasa seperti rumah sakit. Sumber daya manusia dalam sebuah rumah sakit akan dituntut untuk selalu memberikan kinerja yang maksimal dan optimal dalam melayani pasiennya. Perawat mendominasi jumlah tenaga kesehatan di rumah sakit sehingga memegang peranan penting karena perawat bertugas selama 24 jam melayani pasien (Fitrianasari, et al., 2013). Perawat akan dituntut memberikan kinerja yang terbaik karena kinerjanya akan langsung dirasakan oleh pasien. Kinerja perawat menunjukkan besarnya 
JURNAL

MANAJEMEN

INDONESIA

Vol. 15 - No. 1

April 2015 kontribusi yang diberikan terhadap rumah sakit tempatnya bekerja, sekaligus mencerminkan kinerja sebuah rumah sakit karena pasien akan sering berhubungan secara langsung dengan perawat.

Salah satu faktor yang mempengaruhi kinerja perawat adalah organizational citizenship behavior (OCB). OCB adalah perilaku pilihan yang tidak menjadi bagian dari kewajiban kerja formal seorang karyawan, namun mendukung berfungsinya organisasi tersebut secara efektif (Robbins dan Judge, 2008). Rumah sakit tidak hanya mengharapkan perawat yang bekerja sesuai perannya (in-role), tetapi juga perawat dapat memberikan kontribusi lebih (extra-role). OCB ditunjukkan melalui perilaku dimana perawat bersedia dengan kerelaan hati melakukan tugas di luar job discription-nya. Perawat umumnya dituntut untuk memberikan kinerja melebihi harapan dan rumah sakit membutuhkan perawat yang memperlihatkan perilaku good citizen (Robbins dan Judge, 2008). Penelitian Fitrianasari, et al. (2013) menunjukkan bahwa OCB berpengaruh terhadap kinerja perawat sehingga semakin kuatnya OCB terkait dengan perilaku perawat yang suka membantu atau mengutamakan orang lain, berdisiplin tinggi, berperilaku baik terhadap organisasi, baik dan sopan terhadap orang lain dan memiliki rasa toleransi tinggi yang terbentuk secara kuat akan menjadi faktor pendorong kinerja perawat.

Basrah (2012) mengkategorikan beberapa faktor yang mempengaruhi OCB, salah satunya adalah kepribadian. The big five personality dipilih karena pendekatan kepribadian ini paling sering digunakan dalam penelitian perilaku keorganisasian dan sering dikaitkan dengan pencapaian kinerja atau prestasi seseorang (Purnomo dan Lestari, 2010). The big five personality menunjukkan adanya lima dimensi kepribadian utama pada individu (Luthans, 2006). Karyawan dengan karakteristik tinggi pada masing-masing dimensi the big five personality adalah karyawan yang suka hidup berkelompok, aktif, terbuka, suka berteman, hangat, suka menolong, berhati lembut, teliti, tepat waktu, rapi, bertanggung jawab, rileks, tidak mudah emosional, kreatif, dan ingin tahu. Sedangkan karyawan dengan karakteristik rendah adalah karyawan yang suka menyendiri, penakut, pendiam, tidak ramah, sinis, pendendam, lalai, lemah, emosional, depresi, dan konvensional.

Beberapa penelitian dilakukan untuk menguji pengaruh the big five personality terhadap OCB dan kinerja. Penelitian Ingarianti (2014); Kappagoda (2013); dan Fitriyani (2013) menunjukkan bahwa the big five personality berpengaruh positif signifikan terhadap OCB. Penelitian Dyahrini (2008) dan Indarti, et al. (2014) menunjukkan bahwa kepribadian berpengaruh signifikan terhadap kinerja pegawai. Hasil penelitian terdahulu menunjukkan bahwa kepribadian berpengaruh signifikan terhadap OCB maupun kinerja karyawan.

RS Santa Clara adalah salah satu rumah sakit swasta yang terletak di Jln. Biliton No. 15 Madiun. Sebagai organisasi yang bergerak di bidang kesehatan, RS Santa Clara dituntut untuk memberikan pelayanan terbaik bagi pasiennya. Robbins dan Judge (2008) mengatakan bahwa organisasi yang sukses membutuhkan karyawan yang melakukan tugas lebih dari sekedar tugas biasa dan memberikan kinerja melebihi harapan. RS Santa Clara tentu mengharapkan adanya OCB pada diri masing-masing perawat sehingga penelitian mengenai OCB sangatlah penting dilakukan untuk melihat tingkat OCB yang dimiliki oleh perawat. Penelitian ini juga menguji pengaruh tidak langsung the big five personality terhadap kinerja perawat melalui OCB sebagai variabel pemediasi.

Berdasarkan permasalahan yang muncul seperti yang diuraikan sebelumnya, maka rumusan masalah dalam penelitian ini adalah: 1) apakah the big five personality berpengaruh signifikan terhadap kinerja perawat?; 2) apakah the big five personality berpengaruh signifikan terhadap OCB?; 3) apakah OCB berpengaruh signifikan terhadap kinerja perawat?; dan 4) apakah the big five personality 
berpengaruh signifikan terhadap kinerja perawat melalui OCB sebagai variabel pemediasi?

Tujuan penelitian ini adalah: 1) menguji signifikansi pengaruh the big five personality terhadap kinerja perawat; 2) menguji signifikansi pengaruh the big five personality terhadap OCB; 3) menguji signifikansi pengaruh OCB terhadap kinerja perawat; dan 4) mengetahui pengaruh tidak langsung the big five personality terhadap kinerja perawat melalui OCB sebagai variabel pemediasi.

\section{LANDASAN TEORI}

\subsection{The Big Five Personality}

The big five personality (kepribadian model lima besar) menunjukkan adanya lima ciri kepribadian utama pada individu (Luthans, 2006). Menurut McCrae dan Costa dalam Pervin, et al. (2005) kepribadian manusia terdiri dari lima faktor dan manusia cenderung memiliki salah satu faktor kepribadian sebagai faktor yang dominan. Tabel 1 menunjukkan karakteristik tinggi dan rendah untuk setiap dimensi the big five personality.

\begin{tabular}{|c|c|c|}
\hline $\begin{array}{l}\text { Karakteristik pada orang } \\
\text { dengan skor tinggi }\end{array}$ & Dimensi the big five personality & $\begin{array}{l}\text { Karakteristik pada orang } \\
\text { dengan skor rendah }\end{array}$ \\
\hline \multicolumn{3}{|l|}{ Extraversion/ekstraversi } \\
\hline $\begin{array}{l}\text { Suka hidup berkelompok, } \\
\text { terbuka, mudah bersosialisasi, } \\
\text { aktif, optimis, setia, menyukai } \\
\text { kegembiraan, banyak bicara, } \\
\text { berorientasi pada hubungan, } \\
\text { dan suka berteman. }\end{array}$ & $\begin{array}{l}\text { Mengukur jumlah dan intensitas } \\
\text { interaksi interpersonal, tingkat } \\
\text { aktivitas, kebutuhan untuk stimulasi } \\
\text { dan kapasitas kegembiraan. }\end{array}$ & $\begin{array}{l}\text { Suka menyendiri, penakut, } \\
\text { tenang, berorientasi tugas, } \\
\text { pemalu dan pendiam. }\end{array}$ \\
\hline \multicolumn{3}{|c|}{ Agreeableness/mudah akur atau mudah bersepakat } \\
\hline $\begin{array}{l}\text { Senang bekerja sama, hangat, } \\
\text { berhati lembut, percara, suka } \\
\text { menolong, memaafkan, mudah } \\
\text { tertipu, terus terang, dan penuh } \\
\text { kepercayaan. }\end{array}$ & $\begin{array}{l}\text { Mengukur kualitas orientasi } \\
\text { interpersonal individu, rangkaian } \\
\text { yang panjang dari keharusan menjadi } \\
\text { pertentangan dalam berbicara, } \\
\text { perasaan, dan aksi. }\end{array}$ & $\begin{array}{l}\text { Bersikap dingin, tidak ramah, } \\
\text { sinis, kasar, curiga, tidak } \\
\text { koperatif, pendendam, suka } \\
\text { memanipulasi, dan suka } \\
\text { menentang. }\end{array}$ \\
\hline \multicolumn{3}{|c|}{ Conscientiousness/sifat berhati-hati } \\
\hline $\begin{array}{l}\text { Bertanggung jawab, teratur, } \\
\text { dapat diandalkan, disiplin diri, } \\
\text { terorganisir, pekerja keras, } \\
\text { tepat waktu, teliti, rapi, } \\
\text { ambisius, tekun, dan gigih. }\end{array}$ & $\begin{array}{l}\text { Mengukur derajat organisasi } \\
\text { seseorang, ketekunan dan motivasi } \\
\text { untuk mencapai tujuan. }\end{array}$ & $\begin{array}{l}\text { Mudah bingung, tidak teratur, } \\
\text { tidak memiliki tujuan, pemalas, } \\
\text { tidak peduli, lemah, lalai, suka } \\
\text { bersenang-senang, lemah dalam } \\
\text { kemauan, dan tidak bisa } \\
\text { diandalkan. }\end{array}$ \\
\hline \multicolumn{3}{|l|}{ Emotional stability/stabilitas emosi } \\
\hline $\begin{array}{l}\text { Tenang, rileks, } \\
\text { tidak emosional, aman, } \\
\text { merasa puas, tabah, } \\
\text { percaya diri, dan memiliki } \\
\text { pendirian yang tetap. }\end{array}$ & $\begin{array}{l}\text { Mengukur penyesuaian diri vs emosi } \\
\text { yang tidak stabil. Kebalikannya } \\
\text { adalah neuroticsm yang } \\
\text { mengidenfitikasi individu yang } \\
\text { mudah stress, memiliki ide yang } \\
\text { tidak realistik dan menginginkan } \\
\text { segala sesuatu yang berlebihan. }\end{array}$ & $\begin{array}{l}\text { Mudah gugup, khawatir, } \\
\text { depresi, emosional, bersedih, } \\
\text { merasa tidak cukup, dan tidak } \\
\text { memiliki pendirian yang teguh. }\end{array}$ \\
\hline \multicolumn{3}{|c|}{ Openness to experience/terbuka terhadap hal-hal baru } \\
\hline $\begin{array}{l}\text { Kreatif, ingin tahu, imaginatif, } \\
\text { asli, tidak tradisional, dan } \\
\text { sensitif terhadap hal-hal yang } \\
\text { bersifat seni. }\end{array}$ & $\begin{array}{l}\text { Mengukur } \\
\text { pencarian secara proaktif } \\
\text { dan penghargaan pengalaman diri, } \\
\text { toleransi dan penjelajahan yang } \\
\text { tidak familiar. }\end{array}$ & $\begin{array}{l}\text { Memiliki sifat konvensional, } \\
\text { menurut adat, berpandangan } \\
\text { sempit, tidak artistik, tidak } \\
\text { analitis, dan merasa nyaman } \\
\text { dengan hal-hal yang telah ada. }\end{array}$ \\
\hline
\end{tabular}

JURNAL

MANAJEMEN

INDONESIA

Vol. 15 - No. 1

April 2015
Tabel 1.

Ciri The Big Five

Personality

Sumber :

Robbins dan

Judge (2008);

Luthans (2006);

Ingarianti (2014) 


\subsection{Organizational Citizenship Behavior (OCB)}

OCB atau perilaku kewargaan organisasi adalah perilaku pilihan yang

JURNAL

MANAJEMEN

INDONESIA

Vol. 15 - No. 1

April 2015

\subsection{Kinerja}

Kinerja menjadi tolak ukur keberhasilan pelayanan kesehatan yang menunjukkan akuntabilitas lembaga pelayanan dalam kerangka tata pemerintahan yang baik (good governance). Upaya untuk memperbaiki mutu dan kinerja pelayanan klinis pada umumnya dimulai oleh perawat. Menurut Sedarmayanti (2004), kinerja adalah pencapaian/prestasi seseorang berkenaan dengan seluruh tugas yang dibebankan kepadanya. Standar kerja mencerminkan keluaran normal dari seorang karyawan yang berprestasi ratarata, dan bekerja pada kecepatan/kondisi normal. Mangkunegara (2005) menyatakan bahwa kinerja adalah hasil kerja secara kualitas dan kuantitas yang dicapai oleh seorang pegawai dalam melaksanakan tugasnya sesuai dengan tanggung jawab yang diberikan. Gibson dalam Dyahrini (2008) menyatakan terdapat tiga kelompok variabel yang mempengaruhi kinerja, yaitu:

a. Variabel individu, yang meliputi kemampuan dan ketrampilan (fisik maupun mental); latar belakang (keluarga, tingkat sosial, dan pengalaman); dan demografis (umur, etnis, jenis kelamin, dan asal usul).

b. Variabel organisasi, yang meliputi sumber daya, kepemimpinan, imbalan, struktur, dan desain pekerjaan.

c. Variabel psikologis, yang meliputi persepsi, sikap, kepribadian, belajar, kepuasan kerja, dan motivasi. 
Hasibuan dalam Gunawan, et al. (2013) menyatakan terdapat enam macam unsur penilaian sebuah kinerja seseorang, yaitu:

a. Prestasi - penilaian mengenai hasil kerja yang dihasilkan oleh karyawan, baik secara kualitas dan kuantitas.

b. Kedisiplinan - penilaian mengenai sikap disiplin karyawan dalam memenuhi peraturan-peraturan yang ada dan melakukan pekerjaan sesuai dengan instruksi yang diberikan kepadanya.

c. Kreativitas - penilaian mengenai kemampuan karyawan dalam mengembangkan kreativitas untuk menyelesaikan pekerjaannya.

d. Kerjasama - penilaian akan kesediaan karyawan untuk berkerjasama dengan karyawan lain, baik secara horizontal (dengan pimpinan atau bawahan) maupun secara vertikal (dengan sesama rekan kerja).

e. Kecakapan - penilaian mengenai kemampuan karyawan untuk menyatukan dan menyelaraskan bermacam-macam elemen yang terlibat dalam menyusun kebijaksanaan dan dalam situasi manajemen, serta kemampuan karyawan untuk mengambil keputusan dalam batas kuasanya.

f. Tanggung jawab - penilaian mengenai kesediaan karyawan dalam mempertanggungjawabkan kebijaksanaannya, pekerjaan dan hasil kerjanya, sarana dan prasarana yang digunakan, serta perilaku pekerjaannya.

\subsection{Pengembangan Hipotesis}

\subsubsection{Hubungan antara The Big Five Personality terhadap Kinerja}

Gibson, et al. dalam Dyahrini (2008) menyatakan bahwa terdapat tiga variabel yang mempengaruhi kinerja, yaitu: variabel individual, variabel organisasional, dan variabel psikologis. Kepribadian merupakan salah satu faktor dari variabel psikologis sehingga kepribadian memiliki pengaruh terhadap kinerja. The big five personality merupakan salah satu pendekatan kepribadian yang sering digunakan karena adanya keterkaitan antara dimensi-dimensi kepribadian tersebut dengan prestasi kerja individu (Robbins dan Judge, 2008). Purnomo dan Lestari (2010: 146) menyatakan bahwa the big five factor paling sering digunakan dalam berbagai penelitian tentang perilaku keorganisasian dan sering dikaitkan dengan pencapaian kinerja atau prestasi seseorang. Penelitian Dyahrini (2008) dan Indarti, et al. (2014) menunjukkan bahwa variabel kepribadian pegawai berpengaruh signifikan terhadap kinerja pegawai. Berdasarkan uraian tersebut, maka dirumuskan hipotesis sebagai berikut: $\mathrm{H}_{1}$ : The big five personality berpengaruh signifikan terhadap kinerja perawat

\subsubsection{Hubungan antara The Big Five Personality terhadap OCB}

Basrah (2012) mengkategorikan beberapa faktor yang mempengaruhi OCB terdiri dari perbedaan individu, sikap pada pekerjaan sikap, dan faktor-faktor kontekstual, dimana kepribadian termasuk dalam faktor perbedaan individu. Kepribadian dianggap sebagai salah satu faktor yang berpengaruh signifikan terhadap OCB karena kepribadian merupakan sesuatu yang melekat pada individu dan sulit diubah sehingga memiliki pengaruh yang lebih stabil dan bertahan pada OCB (Purba dan Seniati, 2004). Penelitian Ingarianti
JURNAL

MANAJEMEN

INDONESIA

Vol. 15 - No. 1

April 2015 
JURNAL

MANAJEMEN

INDONESIA

Vol. 15 - No. 1

April 2015
(2014); Kappagoda (2013); dan Fitriyani (2013) kepribadian memiliki pengaruh positif signifikan terhadap OCB. Perawat dengan karakteristik tinggi pada masing-masing dimensi the big five personality yang ditunjukkan dengan suka hidup berkelompok, aktif, terbuka, suka berteman, hangat, suka menolong, berhati lembut, teliti, tepat waktu, rapi, bertanggung jawab, rileks, tidak mudah emosional, kreatif, dan ingin tahu akan memiliki OCB yang tinggi pula. Berdasarkan uraian tersebut, maka dirumuskan hipotesis sebagai berikut: $\mathrm{H}_{2}$ : The big five personality berpengaruh signifikan terhadap OCB.

\subsubsection{Hubungan antara $\mathrm{OCB}$ terhadap Kinerja}

OCB adalah perilaku sukarela di luar tuntutan peran (extra-role) yang mampu menunjang efektivitas suatu organisasi. Robbins dan Judge (2008) menyatakan bahwa organisasi yang sukses membutuhkan karyawan yang melakukan tugas lebih dari sekedar tugas biasa mereka, yang akan memberikan kinerja melebihi harapan. Penelitian mengenai OCB telah banyak dilakukan dan menunjukkan bahwa OCB mampu memberikan pengaruh yang signifikan terhadap kinerja karyawan. Hal tersebut sesuai dengan pernyataan Podsakoff, et al. (2000) bahwa OCB memiliki peranan dalam meningkatkan kinerja karena OCB mampu meningkatkan efektivitas organisasi. Penelitian Fitriastuti (2013); Sukmawati, et al. (2013); dan Fitrianasari, et al. (2013) menunjukkan OCB berpengaruh positif signifikan terhadap kinerja. Berdasarkan uraian tersebut, maka dirumuskan hipotesis sebagai berikut: $\mathrm{H}_{3}$ : $\mathrm{OCB}$ berpengaruh signifikan terhadap kinerja perawat.

\subsubsection{Hubungan antara The Big Five Personality terhadap Kinerja dengan OCB sebagai Variabel Pemediasi}

Kepribadian merupakan sesuatu yang melekat pada individu dan sulit diubah sehingga memiliki pengaruh yang signifikan terhadap pembentukan OCB. Karyawan dengan karakteristik kepribadian yang tinggi pada masing-masing dimensi the big five personality menunjukkan tingkat OCB yang tinggi. Karyawan dengan tingkat OCB yang tinggi adalah karyawan yang bersedia melakukan pekerjaan di luar job discription yang diberikan kepadanya. Perilaku di luar peran atau extra role ini memberikan berpengaruh signifikan terhadap kinerja karyawan, dimana karyawan dengan tingkat OCB yang tinggi akan memberikan kinerja yang tinggi pula, sehingga membantu efektivitas sebuah organisasi. Hal tersebut mengindikasi bahwa OCB berperan sebagai pemediasi atau variabel intervening atas pengaruh the big five personality terhadap kinerja perawat. Karakteristik yang tinggi pada dimensi the big five personality perawat memicu peningkatan OCB perawat sehingga mampu berperan terhadap peningkatan kinerja perawat tersebut. Berdasarkan uraian tersebut, maka dirumuskan hipotesis sebagai berikut: $\mathrm{H}_{4}$ : The big five personality berpengaruh tidak langsung terhadap kinerja perawat melalui OCB sebagai variabel pemediasi.

Model penelitian yang diadaptasi dari beberapa penelitian terdahulu digambarkan sebagai berikut:

Gambar 1.

Model Penelitian

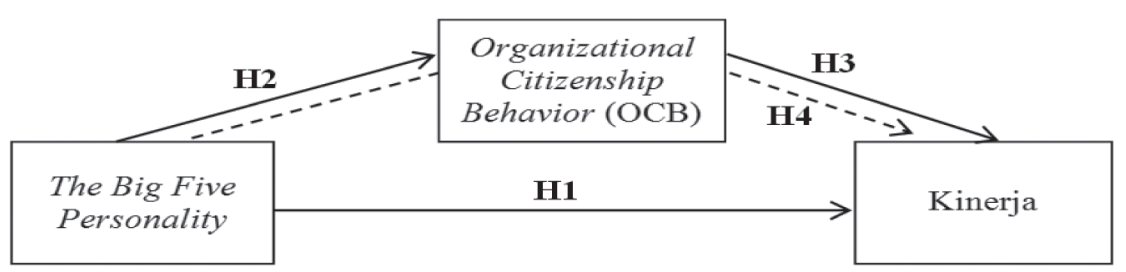




\section{METODOLOGI}

Desain penelitian ini adalah penelitian kausal dimana penelitian ini berguna untuk menganalisis hubungan antara satu variabel dengan variabel lainnya atau bagaimana suatu variabel mempengaruhi variabel lainnya. Populasi dalam penelitian ini adalah perawat di RS Santa Clara Madiun yang berjumlah 54 orang, dan semua dijadikan responden. Penelitian dilakukan di RS Santa Clara, Jln. Biliton No. 15 Madiun dan waktu penelitian adalah Desember 2014 - Februari 2015. Penelitian ini terdiri dari tiga variabel, yakni:

a. Variabel independen, the big five personality menggunakan Big Five Inventory (BFI) yang dikembangkan oleh John dan Srivastava (2014).

b. Variabel dependen, kinerja menggunakan item indikator yang dikembangkan oleh Gunawan, et al. (2013).

c. Variabel mediasi atau intervening, OCB menggunakan item indikator yang dikembangkan oleh Morisson dalam Mas'ud (2004) dan dalam Fitriyani (2013).

Teknik analisis data meliputi statistik deskriptif, uji kualitas data, uji asumsi klasik, analisis regresi bertingkat, koefisien determinasi $\left(R^{2}\right)$, uji hipotesis, dan analisis jalur menggunakan SPSS 17.0.

\section{HASIL DAN PEMBAHASAN}

\subsection{Analisis Statistik Deskriptif}

Kuesioner yang dibagikan kepada responden sebanyak 52 dan kuesioner yang tidak diisi lengkap sebanyak 2, sehingga kuesioner yang dipakai dalam penelitian ini sebanyak 50 kuesioner. Untuk menafsirkan tinggirendahnya rata-rata jawaban responden, dibuat rentang skala sebesar 0,8 . (RS $=(5-1) / 5=5 / 4=0,8)$.

\begin{tabular}{|c|c|c|c|c|c|}
\hline $\begin{array}{l}\text { Variabel } \\
\text { Penelitian }\end{array}$ & Indikator Variabel & $\begin{array}{l}\text { Mean } \\
\text { Indikator }\end{array}$ & $\begin{array}{l}\text { Peringkat } \\
\text { Indikator }\end{array}$ & $\begin{array}{l}\text { Mean } \\
\text { Variabel }\end{array}$ & $\begin{array}{l}\text { Peringkat } \\
\text { Variabel }\end{array}$ \\
\hline \multirow{5}{*}{$\begin{array}{l}\text { The Big Five } \\
\text { Personality } \\
\text { (BIG) }\end{array}$} & Extraversion & 3,72 & Tinggi & \multirow{5}{*}{3,75} & \multirow{5}{*}{ Tinggi } \\
\hline & Agreeableness & 3,84 & Tinggi & & \\
\hline & Conscientiousness & 3,94 & Tinggi & & \\
\hline & Emotional Stability & 3,62 & Tinggi & & \\
\hline & Openness to Experience & 3,64 & Tinggi & & \\
\hline \multirow{5}{*}{$\mathrm{OCB}(\mathrm{OCB})$} & Altruism & 3,84 & Tinggi & \multirow{5}{*}{3,87} & \multirow{5}{*}{ Tinggi } \\
\hline & Conscientousness & 4,12 & Tinggi & & \\
\hline & Courtesy & 3,73 & Tinggi & & \\
\hline & Civic Virtue & 3,86 & Tinggi & & \\
\hline & Sportmanship & 3,82 & Tinggi & & \\
\hline \multirow{6}{*}{$\begin{array}{l}\text { Kinerja } \\
(\mathrm{KIN})\end{array}$} & Prestasi & 4,13 & Tinggi & \multirow{6}{*}{4,06} & \multirow{6}{*}{ Tinggi } \\
\hline & Kedisiplinan & 4,25 & Sangat Tinggi & & \\
\hline & Kreativitas & 3,79 & Tinggi & & \\
\hline & Kerjasama & 4,21 & Sangat Tinggi & & \\
\hline & Kecakapan & 3,93 & Tinggi & & \\
\hline & Tanggung jawab & 4,06 & Tinggi & & \\
\hline
\end{tabular}

Tabel 2.

Rata-Rata Tanggapan Responten terhadap Variabel Penelitian 
JURNAL

MANAJEMEN

INDONESIA

Vol. 15 - No. 1

April 2015

Tabel 3.

Dimensi The Big

Five Personality dan OCB

Responden yang Paling

Dominan

Tabel 4.

Tingkat OCB Responden
Berdasarkan tabel 2 diketahui bahwa rata-rata tanggapan responden terhadap variabel the big five personality berada di peringkat tinggi $(3,75)$ dan dimensi big five personality dengan nilai mean tertinggi $(3,94)$ adalah dimensi conscientiousness. Rata-rata tanggapan responden tentang variabel OCB berada di peringkat tinggi $(3,87)$ dan dimensi OCB dengan nilai mean tertinggi $(4,12)$ adalah dimensi conscientiousness. Rata-rata tanggapan responden terhadap variabel kinerja berada di peringkat tinggi $(4,06)$. Dimensi kinerja dengan nilai mean tertinggi adalah dimensi kedisiplinan dengan peringkat sangat tinggi $(4,25)$ dan dimensi kerjasama dengan peringkat sangat tinggi $(4,21)$, sehingga dapat disimpulkan bahwa kedisiplinan dan kerjasama sangatlah penting dalam kinerja seorang perawat.

\begin{tabular}{|c|c|c|c|c|c|}
\hline $\begin{array}{c}\text { Dimensi The Big Five } \\
\text { Personality }\end{array}$ & $\begin{array}{l}\text { Jumlah } \\
\text { (orang) }\end{array}$ & $\begin{array}{c}\text { Presentase } \\
(\%)\end{array}$ & Dimensi OCB & $\begin{array}{l}\text { Jumlah } \\
\text { (orang) }\end{array}$ & $\begin{array}{c}\text { Presentase } \\
\quad(\%)\end{array}$ \\
\hline Extraversion & 8 & $16 \%$ & Altruism & 8 & $16 \%$ \\
\hline Agreeableness & 12 & $24 \%$ & Conscientousness & 27 & $54 \%$ \\
\hline Conscientiousness & 21 & $42 \%$ & Courtesy & 3 & $6 \%$ \\
\hline Emotional Stability & 4 & $8 \%$ & Civic Virtue & 6 & $12 \%$ \\
\hline Openness to Experience & 5 & $10 \%$ & Sportmanship & 6 & $12 \%$ \\
\hline Jumlah & 50 & $100 \%$ & Jumlah & 50 & $100 \%$ \\
\hline
\end{tabular}

Berdasarkan tabel 3, diperoleh hasil analisis yang menunjukkan kepribadian responden, yakni 8 orang berkepribadian extraversion, 12 orang berkepribadian agreeableness, 21 orang berkepribadian conscientiousness, 4 orang berkepribadian emotional stability, dan 5 orang berkepribadian openness to experience. Dimensi OCB yang paling dominan dimiliki oleh responden, yakni 8 orang memiliki dimensi altruism, 27 orang memiliki dimensi conscientousness, 3 orang memiliki dimensi courtesy, 6 orang memiliki dimensi civic virtue, dan 6 orang memiliki dimensi sportmanship.

\begin{tabular}{|c|l|c|c|}
\hline No. & Tingkat OCB Responden & Jumlah (orang) & Presentase (\%) \\
\hline 1. & Sangat Rendah & 0 & $0 \%$ \\
\hline 2. & Rendah & 0 & $0 \%$ \\
\hline 3. & Sedang & 3 & $6 \%$ \\
\hline 4. & Tinggi & 37 & $74 \%$ \\
\hline 5. & Sangat Tinggi & 10 & $20 \%$ \\
\hline \multicolumn{2}{r}{ Jumlah } & $\mathbf{5 0}$ & $\mathbf{1 0 0} \%$ \\
\hline
\end{tabular}

Tabel 4 menunjukkan bahwa 3 orang memiliki tingkat OCB sedang, 37 orang memiliki tingkat OCB tinggi, dan 10 orang memiliki tingkat OCB sangat tinggi.

\subsection{Uji Kualitas Data (Uji Validitas dan Uji Reliabilitas)}

Uji validitas dilakukan dengan membandingkan nilai $r_{\text {hitung }}>r_{\text {tabel. }}$. Item dinyatakan valid apabila setiap item memiliki $r_{\text {hitung }}>0,279$. Hasil uji validitas menunjukkan bahwa dari 44 item pernyataan the big five personality terdapat 12 item pernyataan the big five personality yang tidak valid sehingga 32 item dinyatakan valid; dari 30 item pernyataan OCB terdapat 3 item pernyataan yang tidak valid sehingga 27 item dinyatakan valid; dan seluruh item pernyataan kinerja ( 20 item) dinyatakan valid. 
Uji reliabilitas dilakukan dengan membandingkan nilai Cronbach Alpha ( $\alpha$ ). Suatu variabel dikatakan reliabel jika $\alpha>0,60$ (Ghozali, 2007). Tabel 5 menunjukkan bahwa semua variabel penelitian ini reliabel

\begin{tabular}{|l|c|c|c|}
\hline \multicolumn{1}{|c|}{ Variabel } & Alpha Hitung & Cronbach Alpha & Keterangan \\
\hline The Big Five Personality (BIG) & 0,933 & 0,600 & Reliabel \\
\hline OCB (OCB) & 0,895 & 0,600 & Reliabel \\
\hline Kinerja (KIN) & 0,930 & 0,600 & Reliabel \\
\hline
\end{tabular}

\subsection{Uji Asumsi Klasik}

Uji asumsi klasik meliputi uji normalitas, autokorelasi, heteroskedastisitas, dan multikolonieritas. Uji normalitas menggunakan uji Kolmogorov-Smirnov, dimana suatu data dikatakan normal apabila nilai asymp.sig (2-tailed) > 0,05 (Ghozali, 2007). Tabel 6 menunjukkan model regresi berdistribusi normal.

\begin{tabular}{|l|l|l|l|l|}
\hline $\begin{array}{l}\text { Variabel } \\
\text { Independen }\end{array}$ & $\begin{array}{l}\text { Variabel } \\
\text { Dependen }\end{array}$ & $\begin{array}{l}\text { Kolmogorov- } \\
\text { Smirnov }\end{array}$ & $\begin{array}{l}\text { Asymp. Sig. } \\
\text { (2-tailed) }\end{array}$ & Keterangan \\
\hline BIG & KIN & 0,718 & 0,681 & Normal \\
\hline BIG & OCB & 0,571 & 0,900 & Normal \\
\hline OCB & KIN & 0,429 & 0,993 & Normal \\
\hline BIG & \multirow{2}{*}{ KIN } & 0,593 & 0,873 & Normal \\
\hline
\end{tabular}

Uji autokorelasi menggunakan uji Durbin-Watson yang mengacu pada Ghozali (2007), dimana bila nilai DW berada di dU < DW < 4-dU berarti tidak terjadi autokorelasi. Tabel 7 menunjukkan keempat model regresi bebas dari masalah autokorelasi sehingga dapat digunakan dalam penelitian

\begin{tabular}{|l|l|c|c|c|l|}
\hline $\begin{array}{l}\text { Variabel } \\
\text { Independen }\end{array}$ & $\begin{array}{l}\text { Variabel } \\
\text { Dependen }\end{array}$ & $\mathbf{d U}$ & $\mathbf{4 - d U}$ & DW & Keterangan \\
\hline BIG & KIN & 1,5849 & 2,4151 & 1,815 & Tidak ada autokorelasi \\
\hline BIG & OCB & 1,5849 & 2,4151 & 1,659 & Tidak ada autokorelasi \\
\hline OCB & KIN & 1,5849 & 2,4151 & 2,124 & Tidak ada autokorelasi \\
\hline BIG\&OCB & KIN & 1,6283 & 2,3717 & 2,144 & Tidak ada autokorelasi \\
\hline
\end{tabular}

Uji heteroskedastisitas menggunakan uji koefisien korelasi Spearman's rho, dimana jika korelasi antara variabel independen dengan residual memberikan $\alpha>0,05$, maka dapat dikatakan bahwa tidak terjadi problem heteroskedastisitas (Priyatno, 2009). Tabel 8 menunjukkan bahwa model regresi bebas dari heteroskedastisitas.

\begin{tabular}{|l|l|l|l|l|}
\hline $\begin{array}{l}\text { Variabel } \\
\text { Independen }\end{array}$ & $\begin{array}{l}\text { Variabel } \\
\text { Dependen }\end{array}$ & $\begin{array}{l}\text { Correlation } \\
\text { Coefficient }\end{array}$ & Sign & Keterangan \\
\hline BIG & KIN & 0,132 & 0,360 & Tidak terjadi heteroskedastisitas \\
\hline BIG & OCB & 0,015 & 0,919 & Tidak terjadi heteroskedastisitas \\
\hline OCB & KIN & 0,066 & 0,647 & Tidak terjadi heteroskedastisitas \\
\hline BIG & KIN & 0,074 & 0,610 & Tidak terjadi heteroskedastisitas \\
\cline { 3 - 4 } OCB & 0,056 & 0,699 & Tidak terjadi heteroskedastisitas \\
\hline
\end{tabular}

JURNAL

MANAJEMEN

INDONESIA

Vol. 15 - No. 1

April 2015

Tabel 5.

Uji Reliabilitas

Tabel 6.

Uji Kolmogorov-

Smirnov

Tabel 7.

Uji Durbin-Watson

Tabel 8.

Uji Koefisien Korelasi Spearman's Rho 
JURNAL

MANAJEMEN

INDONESIA

Vol. 15 - No. 1

April 2015
Uji multikolonieritas dilakukan dengan melihat nilai Variance Inflation Factor (VIF), bila nilai VIF < 10 dan nilai tolerance $>0,10$ berarti tidak terdapat gejala multikolinieritas (Ghozali, 2007). Tabel 9 menunjukkan bahwa model regresi bebas dari multikolonieritas.

\begin{tabular}{|l|l|l|c|l|}
\hline $\begin{array}{l}\text { Variabel } \\
\text { Independen }\end{array}$ & $\begin{array}{l}\text { Variabel } \\
\text { Dependen }\end{array}$ & Tolerance & VIF & Keterangan \\
\hline BIG & \multirow{2}{*}{ KIN } & 0,584 & 1,711 & Tidak ada multikolonieritas \\
\cline { 3 - 5 } OCB & & 0,584 & 1,711 & Tidak ada multikolonieritas \\
\hline
\end{tabular}

\subsection{Uji Hipotesis dan Pembahasan}

Hasil analisis pada tabel 10 menunjukkan bahwa nilai $t_{\text {hitung }}$ $>\mathrm{t}_{\text {tabel }}(5,439 ; 5,844$; dan $8,580>2,010)$ dan nilai $p$-value $<0,05$ $(0,000<0,05)$ sehingga $H_{1}, H_{2}$, dan $H_{3}$ yang diajukan pada penelitian ini diterima.

\begin{tabular}{|c|c|c|c|c|c|c|c|}
\hline Model & Unstd. Beta & Std. Beta & $\mathbf{t}_{\text {hitung }}$ & Sig. & $\mathbf{R}^{2}$ & Adj. $\mathbf{R}^{2}$ & Keterangan \\
\hline \multicolumn{8}{|c|}{ Pengaruh the big five personality terhadap kinerja $\left(\mathrm{Y}_{1}=1,942+0,563 \mathrm{X}_{1}+\mathrm{e}\right)$} \\
\hline Konstanta & 1,942 & & & & & & \\
\hline $\mathrm{X}$ & 0,563 & 0,617 & 5,439 & 0,000 & 0,381 & 0,368 & Signifikan \\
\hline \multicolumn{8}{|c|}{ Pengaruh the big five personality terhadap $\mathrm{OCB}\left(\mathrm{M}=1,982+0,508 \mathrm{X}_{1}+\mathrm{e}\right)$} \\
\hline Konstanta & 1,982 & & & & & & \\
\hline $\mathrm{X}$ & 0,508 & 0,645 & 5,844 & 0,000 & 0,416 & 0,404 & Signifikan \\
\hline \multicolumn{8}{|c|}{ Pengaruh OCB terhadap kinerja $\left(\mathrm{Y}_{2}=0,556+0,900 \mathrm{M}+\mathrm{e}\right)$} \\
\hline Konstanta & 0,556 & & & & & & \\
\hline $\mathrm{M}$ & 0,900 & 0,778 & 8,580 & 0,000 & 0,605 & 0,597 & Signifikan \\
\hline \multicolumn{8}{|c|}{$\begin{array}{l}\text { Pengaruh the big five personality terhadap kinerja dengan } \mathrm{OCB} \text { sebagai variabel pemedias } \\
\left(\mathrm{Y}_{3}=0,451+0,181 \mathrm{X}_{1}+0,752 \mathrm{M}+\mathrm{e}\right)\end{array}$} \\
\hline Konstanta & 0,451 & & & & & & \\
\hline $\mathrm{X}$ & 0,181 & 0,198 & 1,704 & 0,095 & \multirow{2}{*}{0,628} & \multirow{2}{*}{0,612} & Tidak signifikan \\
\hline$M$ & 0,752 & 0,650 & 5,589 & 0,000 & & & Signifikan \\
\hline
\end{tabular}

\subsubsection{Pengaruh The Big Five Personality terhadap Kinerja}

Tabel 7 menunjukkan bahwa the big five personality berpengaruh signifikan terhadap kinerja perawat dengan arah positif, sesuai dengan pendapat Gibson, et al. dalam Dyahrini (2008) yang menyatakan bahwa kinerja dipengaruhi oleh variabel psikologis dan kepribadian merupakan variabel psikologis. Hasil penelitian ini mendukung penelitian Dyahrini (2008) dan Indarti, et al. (2014) bahwa kepribadian berpengaruh positif signifikan terhadap kinerja pegawai. Perawat dengan karakteristik tinggi mampu menunjukkan kinerja yang tinggi pula. Luthans (2006) menyatakan bahwa semakin tinggi nilai rata-rata the big five personality, semakin baik kinerja tim. Nilai rata-rata the big five personality menunjukkan bahwa perawat memiliki nilai yang tinggi sehingga kinerja perawat tersebut dalam sebuah tim juga akan semakin, dimana nilai rata-rata dimensi kinerja, yakni kedisiplinan dan kerjasama memiliki nilai sangat tinggi. Perawat dalam menyelesaikan tugasnya dituntut untuk bekerjasama dalam sebuah tim dan memiliki kedisiplinan sehingga kepribadian yang dimiliki oleh seorang karyawan sangat mempengaruhi kinerjanya, baik secara individu maupun secara tim.
Tabel 9.

Uji Multikolonieritas

\section{Tabel 10.}

Ringkasan Hasil Analisis Regresi 


\subsubsection{Pengaruh The Big Five Personality terhadap OCB}

Tabel 7 menunjukkan bahwa the big five personality berpengaruh signifikan terhadap OCB dengan arah positif. Hal ini mendukung penelitian Fitriyani (2013); Purba dan Seniati (2004); dan Kappagoda (2013) bahwa the big five personality berpengaruh signifikan terhadap OCB. The big five personality memberikan kontribusi yang cukup mempengaruhi munculnya OCB pada diri seseorang sebesar $41,6 \%$. Purba dan Seniati (2004) menyatakan bahwa kepribadian dianggap sebagai salah satu faktor yang berpengaruh signifikan terhadap OCB karena kepribadian merupakan sesuatu yang melekat pada individu dan sulit diubah sehingga memiliki pengaruh yang lebih stabil dan bertahan pada OCB. Perawat dengan karakteristik tinggi pada masingmasing dimensi the big five personality akan memiliki tingkat OCB yang tinggi, dilihat dari kesediaan perawat menggantikan rekan sekerja yang absen, membantu perawat lain yang kelebihan beban kerja, memberikan orientasi kepada perawat baru, datang kerja tepat waktu bahkan lebih awal bila dibutuhkan, menghadiri pertemuan yang dianggap penting secara suka rela, mengingatkan rekan kerja agar tidak lupa menyelesaikan tugasnya, membaca dan mengikuti pengumuman yang dibuat oleh rumah sakit, dan mudah beradaptasi dengan perubahan yang terjadi.

\subsubsection{Pengaruh OCB terhadap Kinerja}

Tabel 7 menunjukkan bahwa OCB berpengaruh signifikan terhadap kinerja dengan arah positif. Hasil penelitian ini mendukung penelitian Fitrianasari, et al. (2013); Fitriastuti (2013); dan Gunawan, et al. (2013) bahwa OCB berpengaruh positif signifikan terhadap kinerja. OCB memiliki peranan dalam meningkatkan kinerja karena OCB mampu meningkatkan efektivitas organisasi. Adanya OCB yang tinggi pada diri perawat mampu meningkatkan kinerja perawat dan menunjang efektivitas dalam organisasi karenasemakin tinggi OCB yang dimiliki oleh seorang karyawan, maka kinerja karyawan itu akan semakin tinggi juga. Robbins dan Judge (2008) menyatakan bahwa organisasi yang sukses membutuhkan karyawan yang melakukan tugas lebih dari sekedar tugas biasa mereka, yang akan memberikan kinerja melebihi harapan. Rumah sakit tentu menginginkan perawat yang mampu memberikan kinerja melebihi standart minimum yang berlaku di rumah sakit tersebut, oleh karena itu, rumah sakit tentu menginginkan adanya OCB yang tinggi pada diri setiap perawatnya.

\subsubsection{Pengaruh The Big Five Personality terhadap Kinerja dengan OCB sebagai Variabel Pemediasi}

Tabel 7 menunjukkan pengaruh langsung the big five personality terhadap kinerja signifikan pada $p$-value 0,000 ; pengaruh langsung the big five personality terhadap OCB signifikan pada $p$-value 0,000; dan pengaruh langsung $O C B$ terhadap kinerja signifikan pada $p$-value 0,000 sehingga dapat disimpulkan bahwa OCB memenuhi syarat sebagai variabel pemediasi pengaruh the big five personality terhadap kinerja perawat. Tabel 7 juga menunjukkan bahwa pengaruh the big five personality terhadap kinerja menurun dan tidak signifikan setelah $O C B$ dimasukkan dalam persamaan regresi sebagai variabel kontrol. Beta ( $\beta$ ) yang semula 0,617 turun menjadi 0,198 dan menjadi tidak signifikan yang menunjukkan bahwa OCB berperan sebagai perantara penuh (full mediation effect) atas pengaruh the big five personality terhadap kinerja, sehingga $\mathrm{H}_{4}$ diterima. 
JURNAL

MANAJEMEN

INDONESIA

Vol. 15 - No. 1

April 2015

Gambar 2.

Diagram Analisis Jalur
Kenny (2015) menyatakan bahwa mediasi penuh terjadi jika variabel $\mathrm{X}$ tidak lagi berpengaruh terhadap $\mathrm{Y}$ setelah M dimasukkan sebagai variabel kontrol. Meskipun secara parsial the big five personality memiliki pengaruh signifikan terhadap kinerja, tetapi ketika OCB dimasukkan dalam persamaan regresi, pengaruh OCB terhadap kinerja $(\beta=0,650)$ lebih kuat dibandingkan pengaruh the big five personality terhadap kinerja $(\beta=0,198$ dan tidak signifikan). Jika dilihat dari pengaruh parsial the big five personality terhadap OCB $(\beta=0,645)$ juga lebih kuat dibandingkan pengaruh the big five personality terhadap kinerja $(\beta=0,617)$, dan hal ini memperkuat peran OCB sebagai perantara penuh pengaruh the big five personality terhadap kinerja.

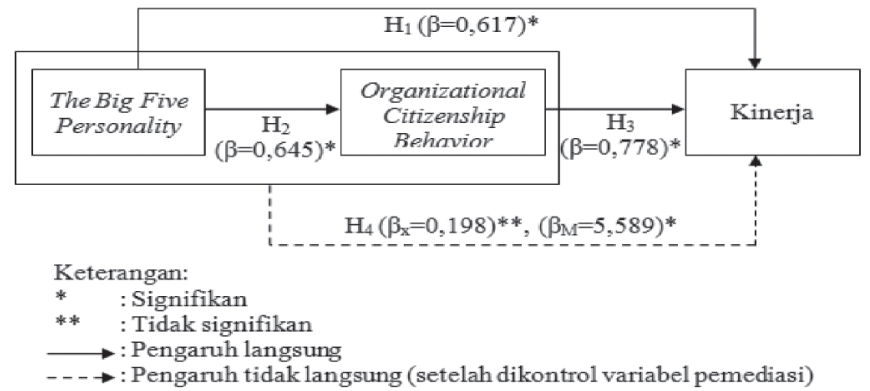

OCB yang dimiliki oleh seorang perawat muncul karena kepribadian yang dimiliki oleh perawat tersebut. The big five personality merupakan sesuatu yang melekat pada individu dan sulit diubah sehingga memiliki pengaruh yang signifikan terhadap pembentukan OCB. Perawat dengan karakteristik kepribadian yang tinggi pada masing-masing dimensi the big five personality menunjukkan tingkat $O C B$ yang tinggi pula, yang selanjutnya $O C B$ yang tinggi dari para perawat berpengaruh berpengaruh terhadap tingginya kinerja perawat. Perawat dengan kepribadian yang aktif, terbuka, suka berteman, hangat, suka menolong, berhati lembut, teliti, tepat waktu, rapi, bertanggung jawab, baik, perhatian, dan senang bekerjasama dengan orang lain akan lebih mudah memiliki perilaku extra-role. OCB ditunjukkan dengan kesediaan untuk membantu rekan kerja, sukarela melakukan kegiatan ekstra di tempat kerja, menghindari konflik dengan rekan kerja, menghargai peraturan di tempat kerja, toleransi pada situasi yang tidak menyenangkan di tempat kerja, memberi saran yang membangun, dan tidak membuang-buang waktu di tempat kerja akan mempengaruhi kinerja perawat tersebut menjadi semakin lebih baik karena perawat tersebut mampu memenuhi kinerja sesuai standar rumah sakit, bahkan menunjukkan kinerja melebihi harapan dan dapat memberikan kontribusi lebih di tempat ia bekerja. 


\section{KESIMPULAN}

Berdasarkan penelitian yang telah dilakukan, kesimpulan dari penelitian ini adalah sebagai berikut:

1. The big five personality berpengaruh positif signifikan terhadap kinerja perawat; the big five personality berpengaruh positif signifikan terhadap OCB; OCB berpengaruh positif signifikan terhadap kinerja perawat; dan the big five personality berpengaruh tidak langsung terhadap kinerja perawat melalui OCB sebagai variabel pemediasi. OCB memiliki peran full mediation pada pengaruh the big five personality terhadap kinerja perawat.

2. Mayoritas perawat (42\%) memiliki kepribadian conscientiousness sebagai dimensi the big five personality yang paling dominan, yang ditunjukkan melalui sikap perawat yang bertanggung jawab, teratur, dapat diandalkan, disiplin diri, terorganisir, pekerja keras, tepat waktu, teliti, rapi, ambisius, tekun, dan gigih.

3. Tingkat OCB yang dimiliki oleh perawat di RS Santa Clara Madiun tergolong tinggi, sebanyak $74 \%$ memiliki tingkat OCB tinggi, $20 \%$ memiliki tingkat OCB sangat tinggi, dan 6\% memiliki tingkat OCB sedang. Mayoritas perawat (54\%) memiliki dimensi conscientousness sebagai dimensi OCB yang paling dominan, yang ditunjukkan melalui kesediaan perawat datang kerja tepat waktu, tidak menggunakan fasilitas kantor untuk urusan pribadi, tidak membuang-buang waktu untuk hal yang tidak berkaitan dengan pekerjaan, tidak mengambil istirahat lebih lama, dan bersedia datang lebih awal bila diperlukan.

\section{DAFTAR PUSTAKA}

Basrah, Hendryadi. 2012. Faktor yang Mempengaruhi OCB. http://teorionline.wordpress.com/2012/03/28/faktor-yang-mempengaruhi-ocb/. Diakses pada 5 November 2014.

Dyahrini, Wien. 2008. Pengaruh Kepribadian Karyawan Terhadap Kinerja Karyawan Akademik Menurut Teori The Big Five Pada Universitas Widyatama. Jurnal Bisnis, Manajemen dan Ekonomi Vol. 9 (No. 3): 1636-1647.

Fitriastuti, Triana. 2013. Pengaruh Kecerdasan Emosional, Komitmen Organisasional dan Organizational Citizenship Behavior Terhadap Kinerja Karyawan. Jurnal Dinamika Manajemen Vol 4 (No.2): 103-114.

Fitrianasari, Dini, Umar Nimran, dan Hamidah Nayati Utami. 2013. Pengaruh Kompensasi dan Kepuasan Kerja Terhadap Organizational Citizenship Behavior (OCB) dan Kinerja Karyawan. Jurnal Profit Vol 7 (No.1): 12-24.

Fitriyani, Windri. 2013. Pengaruh Kepribadian dan Job Embeddedness Terhadap Organizational Citizenship Behavior (OCB) Pada Karyawan PT Hadji Kalla Makassar. Skripsi. Program S1 Manajemen Universitas Hasanuddin. Makassar.

Ghozali, Imam. 2007. Aplikasi Analisis Multivariate dengan Program SPSS. Cetakan IV. Semarang: Badan Penerbit Universitas Diponegoro.

Gunawan, Johana Susanti, Pinkan Datun Solang, dan Endo Wijaya Kartika. 2013. Organizational Citizenship Behavior yang Berpengaruh pada Kinerja Karyawan dan Kepuasan Konsumen di Hotel Sheraton Surabaya. Jurnal Hospitality dan Manajemen Jasa Vol. 2 (No.1): 120-133.

Indarti, Sri, Susi Hendriani, dan Mutia Mahda. 2014. Pengaruh Faktor Kepribadian Pegawai dan Lingkungan Kerja Terhadap Kinerja Pegawai Pada Kantor Regional XII BKN Pekanbaru. Jurnal Ekonomi Vol 22 (No.1): 1-16. 
Ingarianti, Tri Muji. 2014. Hubungan Antara Kepribadian (The Big Five Factor Personality) dengan Organizational Citizenship Behavior pada Karyawan.

JURNAL

MANAJEMEN

INDONESIA

Vol. 15 - No. 1

April 2015 http://download.docstoc.com/document/157779507?key=\&pass=. Diunduh pada 5 Oktober 2014.

John, Oliver P. dan Sanjay Srivastava. 2014. http://moityca.com.br/pdfs/bigfive_John.pdf. Diunduh pada 4 November 2014.

Kappagoda, U.W.M.R. Sampath. 2013. The Impact of Five Factor Model of Personality on Organizational Citizenship Behavior of Non-Managerial Employees in the Banking Sector in Sri Lanka. International Journal of Research in Computer Aplication and Management Vol. 3 (No.6): 168-173.

Kenny, David A. 2015. Mediation. http://davidakenny.net/cm/mediate.htm. Diakses pada 20 Maret 2015.

Luthans, Fred. 2006. Perilaku Organisasi. Edisi Sepuluh. Yogyakarta: Penerbit ANDI.

Mangkunegara, A.A Anwar Prabu. 2005. Manajemen Sumber Daya Manusia Perusahaan. Bandung: PT Remaja Rosdakarya.

Mas'ud, Fuad. 2004. Survei Diagnosis Organisasional Konsep dan Aplikasi. Semarang: Badan Penerbit Universitas Diponegoro.

Pervin, L. A., et al. 2005. Personality Theory and Research. Ninth Edition. New York: John Wiley \& Sons, Inc.

Priyatno, Duwi. 2009.5 Jam Belajar Olah Data Dengan SPSS 17. Yogyakarta: Penerbit ANDI.

Purba, Debora Eflina dan Ali Nina Liche Seniati. 2004. Pengaruh Kepribadian dan Komitmen Organisasi Terhadap Organizational Citizenship Behavior. Makara Sosial Humaniora Vol. 8 (No. 3): 105-111.

Purnomo, Ratno dan Sri Lestari. 2010. Pengaruh Kepribadian, Self-Efficacy, dan Locus of Control Terhadap Presepsi Kinerja Usaha Skala Kecil dan Menengah. Jurnal Bisnis dan Ekonomi Vol 17 (No. 2): 144-160.

Robbins, Stephen P dan Timothy A Judge. 2008. Perilaku Organisasi. Buku 1. Edisi 12. Jakarta: Salemba Empat.

Sedarmayanti, 2004. Pengembangan Kepribadian Pegawai. Penerbit Mandar Maju, Bandung 